\title{
The Contribution of Cell Imaging to the Study of Anterior Pituitary Function and Its Regulation
}

\author{
Edgar Jiménez-Díaz ${ }^{\mathrm{a}, \mathrm{b}} \quad$ Diana Del-Rio ${ }^{\mathrm{a}, \mathrm{b}}$ Tatiana Fiordelisio ${ }^{\mathrm{a}, \mathrm{b}}$ \\ aLaboratorio de Neuroendocrinología Comparada, Facultad de Ciencias, Universidad Nacional Autónoma de \\ México, Mexico City, Mexico; ${ }^{b}$ Laboratorio Nacional de Soluciones Biomiméticas para Diagnóstico y Terapia \\ LaNSBioDyT, Universidad Nacional Autónoma de México, Mexico City, Mexico
}

\section{Keywords}

Pituitary · Live-cell imaging · Fluorescence microscopy ·

Endocrinology $\cdot$ Biological imaging

\begin{abstract}
Advances in the knowledge of the neuroendocrine system are closely related to the development of cellular imaging and labeling techniques. This synergy ranges from the staining techniques that allowed the first characterizations of the anterior pituitary gland, its relationship with the hypothalamus, and the birth of neuroendocrinology; through the development of fluorescence microscopy applications, specific labeling strategies, transgenic systems, and intracellular calcium sensors that enabled the study of processes and dynamics at the cellular and tissue level; until the advent of super-resolution microscopy, miniscopes, optogenetics, fiber photometry, and other imaging methods that allowed high spatiotemporal resolution and long-term three-dimensional cellular activity recordings in living systems in a conscious and freely moving condition. In this review, we briefly summarize the main contributions of cellular imaging techniques that have allowed relevant advances in the field of neuroendocrinology and paradigm shifts that have im-
\end{abstract}

proved our understanding of the function of the hypothalamic-pituitary axes. The development of these methods and equipment is the result of the integration of knowledge achieved by the integration of several disciplines and effort to solve scientific questions and problems of high impact on health and society that this system entails.

(C) 2022 S. Karger AG, Base

\section{Introduction}

For hundreds of years, attempts have been made to discover and understand the secrets of the complex neuroendocrine system. The relevance of its study is unquestionable, given the evolutionary importance and the profound implications that its alterations have worldwide on public health and the quality of life of a large number of people of all ages and socioeconomic groups.

The earliest formal approaches to the endocrine system date back to the times of Aristotle and Galen, when the term pituita (from the Latin pituita, "mucus") was introduced to refer to a protrusion believed to secrete the mucus from the nose, later renamed hypophysis (from the Latin hypo "below" and physis "grow"). Progress in 
the physiological understanding of the endocrine glands accelerated once the concept of internal secretion matured. By the early 20th century, there was already the idea that the endocrine system regulates, correlates, and integrates all local cellular metabolisms [1]. More than 60 years ago it was described how the brain can influence endocrine function through the portal system, which laid the groundwork for studies on the different mechanisms of pituitary control [2]. These investigations revolutionized the existing knowledge at the time and laid the foundations of neuroendocrinology. However, other scientific areas, such as physics, mathematics, and chemistry, have contributed greatly to the achievements and advances in the study of the pituitary gland function and regulation, especially those closely related to the development of cellular imaging. This led to a deeper understanding of biological systems, and the great "boom" of neuroendocrinology in the second half of the 20th century.

\section{Historical Development of Imaging}

The invention of the microscope more than four centuries ago was a milestone for biological research. Improvements in conventional light microscopy and the interest in the detailed characterization and visualization of tissues and individual cells led to the development of staining techniques and dyes for histological samples preparation, included Golgi staining, Indian ink staining, and biological colorations such as trypan blue and those using hematoxylin and/or eosin. These techniques allowed, for example, the first characterizations of the vasculature, the hypothalamic-pituitary connection [3], and the first classification of pituitary cells into three categories: chromophobe cells, acidophilic cells, and basophilic cells [4].

The interest in the problem of differential staining cellular types or components was solved with the advent of immune labeling (1941), nowadays one of the most widespread labeling techniques. Subsequently, finer and more specific labeling strategies have been developed, such as the genetic addition of small-molecule fluorophores $[5,6]$ and naturally or chimera fluorescent proteins, like genetically encoded green fluorescent protein (GFP) [7-10]. The latter undoubtedly revolutionized cellular imaging [11], leading to the development of several fluorescent proteins in a wide range of wavelengths and applications [12], which paved the way for biological research to advance into a new field of understanding processes and dynamics at the cellular and tissue level through fluorescence microscopy (FM) [13].
In the second half of the 20th century, a diversity of FM microscopes and applications were improved, such as the confocal microscope or multiphoton/two-photon microscopy $[14,15]$ and the development of chimeras and new and enhanced fluorophores that allowed the advent of advanced techniques, like fluorescence recovery after photobleaching [15-17], fluorescence resonance energy transfer $[18,19]$, and total internal reflection FM (TIRFM) $[15,20]$. Thus, one of the major questions resolved with this advance has been the understanding of the mechanism of transport and exocytosis of vesicles in the cell, from the trans-Golgi network to the plasma membrane [21], as observed with the use of a GFP chimera (VSVG3-GFP) coupled to the vesicles and real-time imaging [22].

Moreover, the limited spatial resolution of FM resulting from light diffraction (200 nm, laterally) has been overcome by the advent of super-resolution microscopy (SRM) or nanoscopy, a powerful tool for imaging biomolecules and cellular structures at the nanometer scale (typically 10-70 nm, down to $1 \mathrm{~nm}$ ), even in live-cells. SRM groups several types or approaches, such as super-resolution by interference pattern, single-molecule localization microscopy, stimulated emission depletion microscopy, reversible saturable/switchable optical linear (fluorescence) transitions microscopy, photo-activated localization microscopy, stochastic optical reconstruction microscopy, minimal photon fluxes, AiryScan, lattice lightsheet microscopy, and interferometric approaches to increase axial resolution, such as $4 \mathrm{Pi}$, among others [2327].

Before SRM, the limit of the optical resolution had been surpassed with the invention of the electron microscope (EM) [28], achieving high power resolution $(<0.5$ $\mathrm{nm}$ ), which made it the tool of choice for ultrastructural examinations [29]. There are different modalities of EM, either by irradiating through a sample, as in transmission electron microscopy (TEM) or by collecting backscattered or secondary electrons on the surface of a sample, scanning electron microscopy (SEM) [30]. Before EM, it was not possible to resolve particular features of endocrine cells, such as the size of the secretory granules which have dimensions between 100 and $600 \mathrm{~nm}$ [31]. Recently, volume electron microscopy has been developed, which encompasses a set of EM techniques for three-dimensional (3D) analysis and can be performed by TEM or SEM [32]. These techniques include the serial section TEM or SEM (serial section SEM), electron tomography, serial block-face SEM, and focused ion beam SEM [33]. 
Fig. 1. First representations of the pituitary portal vascular system: Cajal drawing of the sagittal section of the pituitary of a mouse stained with the Golgi method (A: nerve lobe, B: glandular lobe, C: infundibulum) (a); first photograph of the pituitary and hypothalamus cleared in xylol of a newborn child from the front, Popa showed the hypophysio-portal system in the stalk of the pituitary (b); SEM photomicrograph of a monkey pituitary (c); in the pituitary gland, changes in blood flow in the portal circulation alter the pattern of exposure of pituitary cells to neurohormones and nutrient supply to facilitate secretion (d). Images reproduced and modified from Cajal 1909 [34] (a) Popa 1930 [178] (b) Page 1977 [37] (c) Le Tissier 2017 [55] (d).
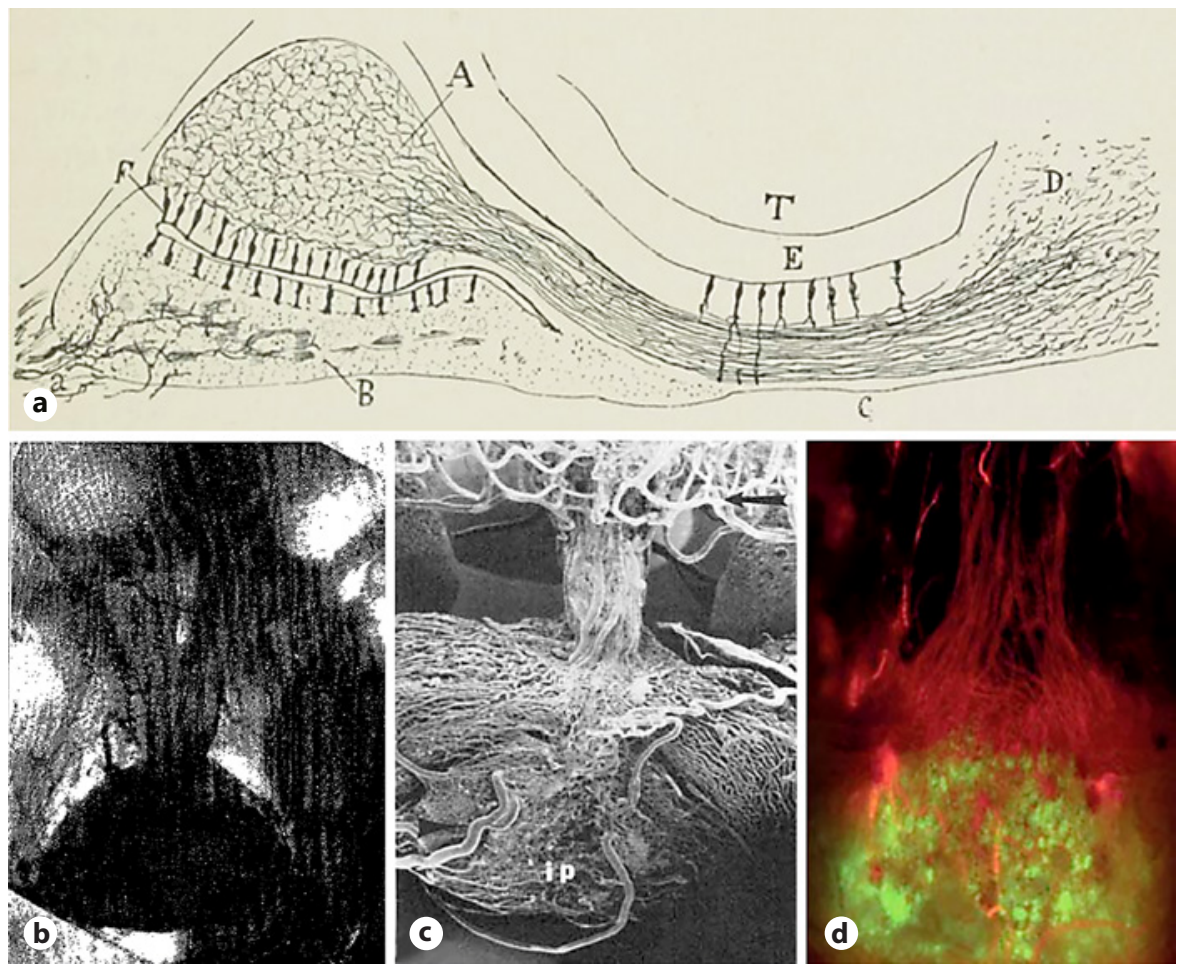

\section{Imaging the Hypothalamic-Pituitary Portal System}

One of the early depictions of the connection between the hypothalamus and the pituitary was drawn by Ramón y Cajal based on the observation of Golgi-stain cells [34] (shown in Fig. 1a). Although Cajal points out the nerve connection, it was until 1930 that Popa and Fielding acquired the first photograph of the pituitary portal system and described a relationship between the hypothalamus and the gland via the pituitary stalk (shown in Fig. 1b). However, they erroneously assumed that blood flow went up the stem toward the hypothalamus [35]. This idea was reformulated in the following years when India ink and other acid markers, such as trypan blue, were used to state that the physiological supply goes from the hypothalamus to the pituitary, establishing the relationship between the median eminence (ME) and the anterior lobe of the pituitary [36, 37].

In the posterior lobe, axons of central nervous system neurons reach the peripheral blood vessels niche, an interface that is facilitated by pituicytes. In both cases, the study of the establishment and the 3D structure of these vascular niches had not been possible given the technical limitations presented by histological sections. Recently, using in vivo fluorescence techniques and the fish model, it was concluded that in the posterior lobe of the pituitary gland the progenitor cells of hypothalamic neurons gradually acquire their neural phenotype and extend their processes toward the pituitary posterior lobe capillary (CAP)plexus which is formed by sprouting and extension of existing vessels under the stimulus of oxytocin, released by the hypothalamic neurons themselves [38-40].

Nowadays, the general consensus is that there are no direct neural connections between the hypothalamus and the anterior lobe, but a complex and unusual network of capillaries [41]. Since the 1970s, it was described that the axons of hypothalamic neurons reach the CAP plexus in the ME [42], we now know that this structure is very dynamic and that glial cells and tanycytes in the ME engulf the axonal terminals and interpose their cellular processes between the axonal terminals and capillaries, for example, when hormonal demand is low [43]. Several factors, such as noradrenaline or ATP, shape this dynamic process [43]. Hypothalamic tanycytes play an important role in the selective permeabilization of molecules to the brain. Recently, using cell tracing and intracellular calcium activity recording, it has been demonstrated that these cells respond to leptin by activating $\mathrm{Ca}^{2+}$ waves, controlling the entry of this hormone into the brain, inducing not only increased food intake and lipogenesis but 
also glucose intolerance by a decrease in insulin secretion by pancreatic $\beta$ cells [44]. Tanycytes also convert brain glucose into lactate which they transmit to the arcuate proopiomelanocortin neurons [45].

The CAP plexus in the hypothalamus and pituitary is complex and dynamic. The ME is not just the site where neuronal axon terminals release neurohormones and molecules into the portal CAP system, in recent years it has been demonstrated that it is also a passage of the signals that are in the blood to the brain, as is the case of ghrelin [46, 47]. Moreover, employing opto and chemogenetic manipulation, it was recently confirmed that melanin-concentrating hormone expressing neurons, key regulators of energy and glucose homeostasis, change ME permeability linking signals of the energy state of the organism with circadian rhythms [48]. Study of the 3D conformation of the vascular network in the anterior pituitary and its relationship with endocrine cell organization and hormonal secretion has recently begun [49]; establishing that capillaries are organized in a complex network forming inner loops and that they are highly correlated with endocrine cells, determining in many cases their morphology and activity [50]. In addition, it has also been possible to observe changes in vascular morphology (number, diameter, and shape) in glands, which can result in dramatic alteration in pituitary tumors [51].

One of the fundamental elements that make the hypothalamic-pituitary portal system functional is the presence of perivascular cells, which differ from smooth muscle, and whose function is not fully understood. It was not until 1989 that SEM images clearly evidenced their presence in the pituitary CAP network [52] (shown in Fig. 1c). These works define pericytes as a type of wall cell that is found throughout the system and were the first to suggest that the pituitary portal system should not be considered as veins, but as fenestrated capillaries covered by pericytes with highly branched cytoplasmic processes [52] that also contribute to the matrix formation [53]. Recently, using SEM, different shapes of pericytes (oval, elongate, triangular, and multiangular) have been observed whose proportion, except for oval pericytes, is higher with physiological changes such as castration [54].

Advances in imaging techniques have made it possible to demonstrate that the pituitary vascular system is highly dynamic [55] and that, contrary to its original description, it not only serves to provide nutrients and oxygen to cells but is also key to generate hormonal pulses [56, 57] (shown in Fig. 1d). In more recent studies, it was possible to measure the blood flow velocity in the pituitary capillaries of growth hormone (GH)-EGFP transgenic mice, using a fluorescence microscope with an objective with a long working distance, $2.8 \mathrm{~cm}$ [56]. A detailed review of these was performed by Schaeffer et al. [58]. However, the relevance of the vasculature in the pituitary and its role in the generation of hormonal pulses has not been fully understood. It is now known that the CAP bed influences gland morphology and network formation $[59,60]$ and that the endothelium-pericyte-endocrine cell unit probably acts in a coordinated way to generate the pulses.

\section{The Pituitary Endocrine Cells Type}

Initially, most of the morphological correlations between the type of pituitary hormone contained in the secretory granules and endocrine cell type were made by observing the cellular changes derived from the ablation of an organ, from a lesion, or in a certain physiological condition [61]. Later, when histochemical techniques were developed and the antibodies could be coupled to enzymes that generated a color, the hormones contained in the cells were identified [62]. Although at that time these were still somewhat difficult and imprecise techniques [63], allow to establish the presence of five endocrine cell types: somatotrophs, lactotrophs, thyrotrophs, gonadotrophs, and corticotrophs [64]. However, in order to identify each of these cells in vivo and be able to study their function, it was necessary to use other techniques such as gene targeting in embryonic stem cells, to generate mice in which Cre recombinase is coexpressed with specific proteins, for example, gonadotropin-releasing hormone $(\mathrm{GnRH})$ receptor [65], glycoprotein hormone alpha-subunit [66], and thyroid-stimulating hormone beta-subunit [67] or by transgenesis to express hormone fragments fused in frame with a fluorescent protein $\mathrm{GH}$ [68], prolactin (PRL [69]), luteinizing hormone (LH [70]), and proopiomelanocortin [71].

For a long time, the pituitary was considered to be a mass of randomly arranged secretory cells. During the late 20th century, it became possible to reproducibly and reliably study both characteristics of each cell type as well as the interactions and relationships between cells and their dynamic changes (reviewed in [72]). The development of fluorescent techniques [73] enabled the modification of the original pituitary concept to show that there is a highly interdigitated organization of cellular networks with homotypic and heterotypic interactions [74], such that the absence of one cell type affects the network 
operation of another cell type [75]; for instance, the absence of corticotrophs modifies the structure and organization of gonadotrophs [70], the absence of gonadotrophs affects lactotrophs [76], and the deficiency of somatotrophs can affect more than one network [77].

Cellular networks are established from embryonic development. The corticotrophs are the first endocrine cell type to form homotypic interactions, probably influencing the organization of other cell networks such as the gonadotrophs that appear at e17.5 [78]. Similar to corticotrophs, GH cells appear as small isolated cells and by e18.5 they have formed strands [78]. In adults, the cellular organization is modified according to physiological conditions, such as lactation and puberty [79], wherein a very robust change in the organization of lactotrophs has been described being remarkable that the network is able to structurally memorize previous challenges $[57,79]$; or somatotroph that has a sexually dimorphic network (higher proportion of responding cells in males than in females) regulated by gonadal steroids, whose activity allows a 1,000 -fold rise of GH levels over basal levels in vivo [8082]. These cellular networks can be remodeled through a mechanism of cellular process extension and cell mobility described in mammals and fishes in gonadotrophs [83-85] and somatotrophs cells [82].

In recent years, interest in reconstructing in vitro $3 \mathrm{D}$ microenvironments close to in vivo structures has increased [86]; however, the pituitary has not been as well explored in this regard as other organs [87]. Diverse techniques like cell aggregates and hanging drops have been used for the study of paracrine signaling and its influence on rat pituitary cells $[88,89]$. Thereby, Denef s group demonstrates that factors such as T3, GHRH, glucocorticoids, among others, regulate the expression of different genes and the relationship in the cellular populations of the aggregates [90-93]. With some limitations, recent work has shown that this type of tool can be an option for the controlled study of cell morphology and interaction in the pituitary, with confocal microscopy and SEM suggesting a similar cell morphology as in vivo with the in vitro 3D experiment [94].

Cell-cell interaction is highly relevant for an appropriate pituitary tissue organization and hormonal secretion [72]. Although there is abundant evidence of the role played by tight junctions, adherens junctions, desmosomes, and gap junctions regulating several processes such as proliferation, death, differentiation, migration, and secretion [95-98], so far we do not have a complete view of the complex and dynamic homo and heterotypic relationship of the anterior pituitary endocrine cells.

Cell Imaging and Pituitary Function

\section{Hormone Production and Secretion by Imaging}

Identification of the pituitary as a secretory gland arose in the 18th century [99]. Later, the first clinical observations were made based on the effect of chemical messengers (hormones) on the control of physiological functions such as growth or organ activity [100]. Even before imaging, it was known from biochemical and physiological studies that the anterior pituitary produced at least six hormones: GH, corticotropin, PRL, TSH, LH, and follicle-stimulating hormone.

Hormonal secretion depends on multiple factors and the integration of systemic and internal signals, which include autocrine and paracrine mechanisms and the relationship of hetero- and homotypic cellular networks and transcription factors that determine hormonal gene transcription. Recently, quantum dots (semiconductor nanoparticles [101]) have been used to investigate the intracellular localization of both pituitary hormones, GH and PRL, and their mRNA simultaneously in 3D arrays $[102,103]$. Other dynamic fluorescent methods, such as the expression of luciferase or destabilized enhanced GFP drive by the PRL gene expression, have allowed researchers to establish that the synthesis of hormones (PRL) although it is observed stochastically in small groups, is a coordinated event throughout the gland $[104,105]$. Likewise, multiple levels of transcription rates and dynamics were also identified between embryonic and adult pituitary glands; the embryonic tissue displayed shorter durations of high-expressing states than the adult, which in turn exhibited local transcriptional coordination between PRL-expressing cells [106].

The secretion of pituitary hormones is an event that depends on the intracellular increase in calcium. In studies carried out with the fluorescent probe FM 1-43 [107], it was observed that lactotrophs have at least two mechanisms of exocytosis that allow them to enhance their secretory response to stimuli: increase of the fusion points at the plasma membrane and increased compound exocytosis [108]. Other studies support this idea, using a fluorescent $\mathrm{pH}$ sensor [109] or other endocrine cells, such as the pancreas $[110,111]$. The kinetics, transport, fusion, and exocytosis [112] of secretory granules have been studied in different cell types, such as adrenal medulla $[113,114]$ and pancreatic beta cells $[115,116]$ combining TIRFM and GFP expression. Calcium is not only required for vesicle fusion but also for vesicle mobilization from the internal reservoirs toward the plasma membrane [112]. In the pituitary $[117,118]$, this technical approach has been used to describe that the lack of exon 3 in the GH

Neuroendocrinology 2023;113:179-192 183 

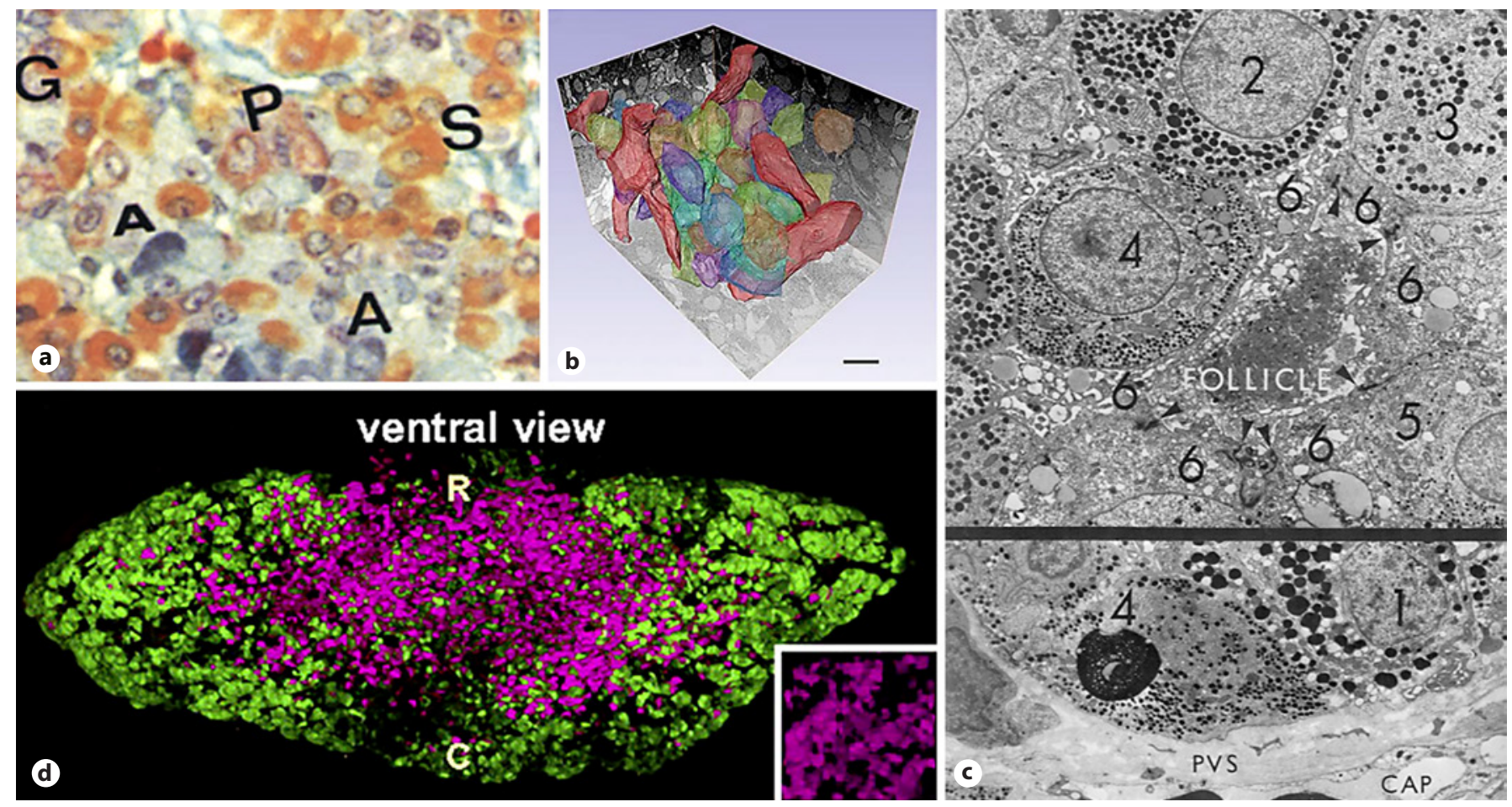

Fig. 2. Deciphering pituitary ultrastructure and cells network through evolving imaging techniques. a Tissue staining with Attia's tetrachrome staining technique of adenohypophysis of a bitch in the anoestrus phase of the cycle: PRL cells: red (P); TSH cells: yellow to yellow-orange (S); ACTH cells: greyish violet (A); Gonadotropic cells: greenish-blue (G). b FIB/SEM tomography reconstruction of the anterior pituitary gland, showing $3 \mathrm{D}$ view of blood vessels and endocrine cells together. c Electron microscopy image of human pituitary cells filled with secretory granules of differing sizes and distinctive electron-density. At least five secretory cell types can be seen, with CAP shown at the bottom, with fenes- trated epithelium and well-developed PVS. d Gonadotroph and corticotroph cell network development, ventral view of double E18.5 POMC-EGFP (green) and LH-cerulean transgenic pituitary showing initial appearance of $\mathrm{LH}$-cerulean cells in the rostromedial AL, in contrast to POMC-EGFP cells that are more prominent in the lateral wings: R; C. Images reproduced and modified from Attia 1978 [63] (a), Yoshitomi 2016 [119] (b), Bergland 1969 [177] (c), Budry 2011 [70] (d). FIB, focused ion beam; POMC, proopiomelanocortin; ACTH, corticotropin; PVS, perivascular space; CAP, capillary; R, Rostral; C, caudal. gene (autosomal dominant GH deficiency type II) produces few secretory vesicles but accumulated secretory products in amorphous cytoplasmic aggregates [118]. However, TIRFM is an underexplored imaging technique for the study of the pituitary.

The secretion event and the generation of hormonal pulses in the bloodstream is a complex phenomenon not yet understood. The full 3D cellular architecture of the anterior pituitary tissue [119] (shown in Fig. 2b) revealed that contrary to the idea conceived that endocrine cells are in apposition of the vessels to secrete their content, approximately $30 \%$ of these are isolated from the perivascular space of the tissue [119]. These observations raise the possibility of having different modes of secretion according to hormonal requirements; for instance, fast pulses can occur by the secretion of cells in apposition with capillaries or slow pulses by those isolated in the parenchyma. This hypothesis has been revised with more recent techniques by Mollard's group [56], where the coordination between the circulation and the secretory bursts to generate a hormonal pulse was modeled in vivo by the elimination of fluorescent markers from the parenchyma of the gland toward the blood vessels (shown in Fig. 2d). They observed that significant amounts of the largest markers accumulated in a perivascular compartment, similar to a reserve or bank for later sudden release [56].

Just a few years ago, the hypothalamic-pituitary regulation was established by three types of regulation: the agnathan diffusional type, the teleost direct innervation type, and the vascular type seen in all other vertebrates [120]. However, Golan et al. [121] used transgenic zebrafish 
models to demonstrate that for instance gonadotropin regulation by $\mathrm{GnRH} 3$ combines neuroglandular and neurovascular components, breaking the established dogma.

\section{Imaging the Intracellular Calcium Activity}

Calcium $\left(\mathrm{Ca}^{2+}\right)$ is a ubiquitous intracellular signaling molecule that controls numerous cellular processes, including fertilization, proliferation, development, learning and memory, contraction, gene expression, and secretion [122]. The magnitude, spatial and temporal aspects of signaling make this enormous range of processes possible [123]. The $\mathrm{Ca}^{2+}$ signaling system has a very large combination of molecular components (toolkit) that in each cell can be mixed to produce a particular response, not just with heterogeneity between cell types but also amongst homotypic cells [123]. Generally, cells at rest have an intracellular calcium concentration $\left(\left[\mathrm{Ca}^{2+}\right]_{\mathrm{i}}\right)$ of $100 \mathrm{nM}$ but are activated when this level rises to roughly $1,000 \mathrm{nM}$. The toolkit is composed of elements that increase the $\left[\mathrm{Ca}^{2+}\right]_{\mathrm{i}}$, through release from internal stores or external medium, and pumps, exchangers, and binding proteins that modulate $\mathrm{Ca}^{2+}$ in the cytoplasm and restore the resting state [123].

As in other excitable cells, endocrine pituitary cells present rises in $\left[\mathrm{Ca}^{2+}\right]_{i}$, either spontaneously or following a stimulus, these rises can be produced by the entrance of extracellular $\mathrm{Ca}^{2+}$ through voltage-gated calcium channels but also from by the exit of this ion from the intracellular reservoirs $[124,125]$. Depending on the cell type, this activity can generate localized or global $\mathrm{Ca}^{2+}$ signals, reaching the threshold for hormone secretion [124]. Each adenohypophyseal cell type has a distinctive fingerprint in terms of its intracellular calcium response [126, 127]. Some other intracellular pathways are important for hormone synthesis and secretion, such as the activation of adenylate cyclase, leading to an increase in cAMP, which in turn leads to an increase in protein kinase A activity. However, fluorescent sensors for these molecules are not common, and their use in imaging is limited. For instance, some of the possibilities that could now be used are assays for protein kinases that utilize a variety of strategies to detect phosphorylation of peptide and protein substrates [128], as well as a red fluorescent cAMP indicator which is a fluorescence resonance energy transfer fluorophore [129] or the yellow fluorescent protein-based cAMP indicator [130].

For a long time, $\mathrm{Ca}^{2+}$ measurements and secretion were performed using the patch-clamp electrophysiology technique $[124,131,132]$. Since then it has been known that secretory activity is related to intracellular $\mathrm{Ca}^{2+}$ activity [133]. However, this technique has the limitation of measuring one cell at a time and the difficulty of recognizing the registered cell type, although there are electrophysiological studies that use fluorescent sensors such as genetically encoded proteins [134] to easily identify the cells of interest as gonadotrophs [135]. At the end of the last century, the development of a series of fluorescent $\mathrm{Ca}^{2+}$ sensors and new microscopes, such as one- or twophotons confocal microscopes, allowed the study of the activity in time of several cells, simultaneously and with high spatiotemporal resolution [136] or even more, cellular activity in free-moving animals with the miniaturized microscopes, "miniscopes" [137]. These indicators can be coupled to an ester molecule and thus cross the cell membrane, changing their fluorescence intensity or wavelength as a function of $\mathrm{Ca}^{2+}$ concentration [138]. Since then, these sensors have improved and diversified greatly, to the point that some of them could be specifically expressed by a particular cell type [139].

In recent years, in order to understand the functioning of neural and neuroendocrine networks, the need arose to develop new imaging methods and tools that would allow in situ visualization of changes in intracellular $\mathrm{Ca}^{2+}$ activity, and thus the study of hormonal secretion in the pituitary. Consequently, genetically encoded calcium indicators [140] were created, the most widely used being a circular permutation offluorescent proteins, such as GcAMPs and pericams, which are based on the alteration of the conformation of a fusion protein containing a calmodulin (which binds to $\mathrm{Ca}^{2+}$ ) and a fluorophore, whose intensity varies as a function of $\mathrm{Ca}^{2+}$ concentration [141]. The most common form for the specific expression of the genetically encoded calcium indicators is based on the Cre/loxP system [142]. The transgenic system uses the expression of Cre (Cre recombinase; tyrosine site-specific recombinases) by a promoter that specifically targets the cell or tissue of interest. Second, this enzyme recognizes the specific DNA fragment sequences called loxP and mediates site-specific deletion of this sequence which flanked DNA containing, for example, the protein of interest to be expressed as the GFP, GcAMP, among others [143].

\section{Calcium Activity and Endocrine Pituitary Cellular Networks}

The intracellular $\mathrm{Ca}^{2+}$ activity of adenohypophyseal cells has been extensively evaluated in cell culture, so we will only refer to a few examples that illustrate how ad- 
vances in imaging have allowed us to change some of the concepts described. Numerous studies have shown that gonadotrophs isolated in primary culture exhibit robust and stereotyped dose-dependent intracellular $\mathrm{Ca}^{2+}$ signals in response to different concentrations of $\mathrm{GnRH}$ $[144,145]$. An increase in $\left[\mathrm{Ca}^{2+}\right]_{\mathrm{i}}$ triggers exocytosis and gonadotropin synthesis [146]. It has long been assumed that the different $\mathrm{Ca}^{2+}$ patterns (oscillatory, biphasic, and transient) observed with increasing doses of GnRH underlie just the dose-dependent increase in gonadotropin secretion. However, it has also been suggested that these patterns encode other cellular functions [146]; for example, $\mathrm{Ca}^{2+}$ biphasic responses were associated with $\mathrm{LH}$ secretion and oscillatory responses to $\mathrm{LH} \beta$ subunit synthesis [146]. The possibility of improving the techniques to measure the variations in $\left[\mathrm{Ca}^{2+}\right]_{\mathrm{i}}$ in slices, has allowed us to document important differences to what is observed in cells in culture. For instance, the different $\mathrm{Ca}^{2+}$ patterns observed as dose-dependent, are no longer so clear in tissue slices, in which the number of gonadotrophs that respond to a GnRH concentration gradient is not constant and $58 \%$ of cells do not have a sequence of these canonical $\mathrm{Ca}^{2+}$ patterns; even some cells exhibit an atypical (nonoscillatory) response, not seen in culture, regardless of stimulus concentration [147].

In somatotrophs, using a combination of single-cell techniques (Fura-2 with digital microscopy and hemolytic plaque assay) in late $1987,\left[\mathrm{Ca}^{2+}\right]_{\mathrm{i}}$ and hormonal GH secretion were measured simultaneously. The authors reported spontaneous $\mathrm{Ca}^{2+}$ oscillations with different frequencies and amplitudes in specific cells and related these oscillations to GH secretion [148]. Many years later, it was also demonstrated that $\mathrm{Ca}^{2+}$ outflow from intracellular stores could not only enhance GH secretion but also increase RNA expression [149]. Using a combination of imaging techniques, it was shown that somatotrophs are organized in a continuum connected by adherent junctions that permeate the entire gland and exhibit the three primary characteristics of biological networks: robustness of architecture throughout life, modularity correlated with pituitary GH contents, and body growth, and connectivity with stereotyped motifs, especially cellular synchronization coordinating activity [80]. Furthermore, the in vivo responses of the somatotropic cell network were shown to be sexually dimorphic, with a greater proportion of cells responding synchronously in males than in females, resulting in greater $\mathrm{GH}$ release [81]. These findings have been a turning point in the thinking about the structure and organization of somatotrophs in particular but will undoubtedly be applicable to other endocrine cells.
An important imaging tool developed in the last decade is the miniscope, a system that seeks to integrate the capabilities of a microscope into a small device $(<2 \mathrm{~g})$ [150]. The miniscope is based on technological developments such as CMOS [151] image sensors, LED diodes [152], and GRIN lenses; elements that make possible an extremely reduced optical path and whose portability facilitates incorporation into living systems without interfering with their free movement, in addition to reducing motion artifacts in the recordings. Furthermore, unlike fiber photometry, with the miniscope, it is possible to distinguish the $\mathrm{Ca}^{2+}$ activity of more than one cell individually. Its use in neuroendocrinology research has begun [153]. Recently, the use of the miniscope to record somatotrophs cell activity in freely moving animals has been published [154]. This work is an example of the use of a combination of the latest imaging techniques since it uses tissue transparency (iDisco) for morphological characterization, the injection of viral vectors for the expression of calcium sensors, the recording of intracellular calcium in anesthetized and head fixed miniscope recordings, the expression of opsins for the control of somatotroph cell activity, as well as the monitoring of hormonal secretion by ELISA [154]. This represents a significant advance in the generation of tools that allow not only observation of cellular activity in situ, but to do this under particular conditions and to perform longitudinal studies of events of different temporality, for example, short-duration processes (such as calcium signals that control hormonal exocytosis) or others of slow evolution, such as tissue remodeling in health and disease over a period of days to weeks.

It is clear that the magnitude of hormonal pulses in the systemic circulation is not just the product of the simple sum of individual endocrine activity, but of cellular interactions in the tissue as a whole. Thus, the development of powerful tools such as the miniscope encourages the exploration of new facets of the behavior of these neuroendocrine cellular networks under conditions in which the anatomical-functional environment of the tissue is preserved, from tissue slices to the pituitary of anesthetized or freely moving animals.

\section{Study of Hypothalamic-Pituitary Axis Function by Imaging}

The concept of neurosecretion was originally based on observations made with light microscopy and later reaffirmed with histological staining and EM [155]. Great ef- 
forts have been made to record and manipulate the action of hypothalamic neurons, and thus to understand their impact on hormone secretion. The stereotaxic placement of fine electrodes for electrical stimulation in various parts of the hypothalamus showed that it was possible to modulate, stimulate or inhibit, the secretions of practically every pituitary hormone [36]. However, it will always be preferable to study cells in vivo and be able to see their activity, since many cell networks, factors, and other anatomical-functional conditions are essential. Recent studies seek to develop in vitro strategies that allow the reconstruction of a controlled microenvironment that most closely resembles reality with organs-on-a-chip, organoids, and tissue engineering [156]; alternatively, there is a stream of analysis that seeks to advance ex vivo and in vivo strategies. Campos et al. [157] published an extensive review of the new techniques used to study the hypothalamus.

Two of the great inventions that have revolutionized modern life are fiber optics and lasers (Light Amplification by Stimulated Emission of Radiation). Both are based on the discoveries and observations of scientists, mainly physicists, made over two centuries [158] until the development of solid-state lasers [159], and led to the recent development of optogenetics and fiber photometry [160]. These techniques have been used to examine the activity of neuronal populations in freely moving animals [161]. Thus, using fiber photometry and the GCaMP6 calcium sensor in free-moving mice, it was shown that arcuate nucleus kisspeptin (ARNKISS) neurons have episodes of synchronous activity with a frequency that can vary between 43 and $347 \mathrm{~min}$ [162], and these periods are shortened and became closer in castrated animals [163]. Moreover, the expression of designer receptors exclusively activated by designer drugs into hypothalamic astrocytes surrounding $\mathrm{GnRH}$ neurons has demonstrated that their activation increased GnRH neurons electrical activity augmenting LH levels in vivo, without affecting ARNKISS [164].

To control neuronal activity, the expression of algal opsins (photosensitive membrane proteins) has been used in mammalian cells $[165,166]$. Examples are channelrhodopsins, which is a blue light-activated ion channel $(480 \mathrm{~nm})$ that generates depolarization at the plasma membrane, and halorhodopsin, which is a red light-activated chloride pump $(570 \mathrm{~nm})$ [167]. This technique has been combined with the recording of $\mathrm{Ca}^{2+}$ population activity with fiber optics in freely moving animals to demonstrate the role of ARNKISS neurons in the regulation of GnRH and LH secretion [163], demonstrating for the first time directly that activation of ARNKISS neurons for $1 \mathrm{~min}$ generates $\mathrm{LH}$ pulses in the blood circulation in freebehaving mice, and their inhibition for $30 \mathrm{~min}$ suppresses it [163].

The generation of hormonal pulses requires not only meeting the oxygen and nutrient demands of thousands of active endocrine cells but also the precise input of stimuli from the hypothalamus and peripheral circulation and the coordinated release of hormones into the bloodstream. We are beginning to understand how this is achieved; endocrine cell activity has to be temporarily correlated with blood flow. To date, a considerable number of studies have been conducted to understand how hormonal secretion is regulated and based on this how it can be modified/restored to prevent or reverse common hormonal disorders. However, little is known of how this process occurs dynamically in vivo.

The development of new in vivo approaches to measure local blood flow has made it possible to quantify the velocity of blood flow [56], the oxygen partial pressure, and the cellular activity with single-cell resolution and secretion in the mouse pituitary. GHRH injection has been shown to stimulate somatotropic network activity and GH secretion, with a temporal association with increased blood flow rate and oxygen supply [56]. This study has been a milestone for the knowledge of the hypothalamic-pituitary function and is the product of the integration of many knowledge and techniques developed so far.

\section{New Insights}

Scientific questions are complex, increasingly; all sciences will be required to engage in an interdisciplinary scope to develop conceptual and experimental strategies that allow us to understand systems as complex and vast as the neuroendocrine. The answers to the biological and clinical questions that lie ahead must necessarily start from the search for new ideas in physics, chemistry, mathematics, and biology. In this sense, the development of new in vitro culture techniques, and the interest of physicists, mathematicians, and biologists in understanding and modeling cellular interactions with the appropriate microenvironment, will allow the development of new organ-on-chip [168] or organoid culture [169] techniques, conditions that may allow simulation of cellular and physiological conditions in a more realistic way. The results obtained so far are encouraging $[94,170]$, but further developments will be necessary to include factors as 
important as blood flow, incorporating new advances in microfluidics and microfabrication [171]. With these modifications, it will be possible to evaluate controlled stimulation-secretion experiments.

Concerning to the anatomical and morphological description, it is not difficult to think that in the coming years we will be able to make $3 \mathrm{D}$ reconstructions in which the anatomical-morphological relationships of the tissue in a given context can be observed instantly and reliably and that it will be possible to compare them with any change that may occur in it. Substantial progress has been made; examples of this are the advances in instrumentation and visualization methods that allow increasing the resolution in all optical-axes such as light-sheet microscopy [172], as well as methods of tissue treatment that match the refractive index of cells with the medium, making it transparent [173].

Undoubtedly, the advancement of the miniscope [150], the two-photon miniscope [174], and optogenetics [160], as well as their combination [175] and the development of 3D cell activity recordings in awake mice and in adult brain slices [176], will allow progress in the knowledge of cell activity and its control in conscious animals and deeper understanding of neuroendocrinology.

Over the years, the field of neuroendocrinology has undergone relevant paradigm shifts. The problem posed by the neuroendocrine system, like any complex system given the nature and organization of its constituent elements, can hardly be approached from the perspective of a single discipline. Important advances in the physical, chemical, and mathematical sciences have allowed the development of tools and techniques such as microscopy to explore, from the molecular and cellular level to the interactions between diverse systems, and to understand individual and collective functioning in a truly common trans- or interdisciplinary effort that has allowed scientific progress in general in recent decades. Neuroendocrinology is, therefore, a fertile field of research in which multidisciplinary and interdisciplinary research is favored, and to a large extent of a translational nature, thus narrowing the bridge between basic research and the resolution of problems of high impact on health and society.

\section{Acknowledgment}

The authors would like to thank Claudia Segal Kischinevzky for her invaluable insights.

\section{Conflict of Interest Statement}

The authors have no conflicts of interest to declare.

\section{Funding Sources}

This research was funded by ANR-CONACYT 273513. Edgar Jiménez-Díaz is a doctoral student from Programa de Doctorado en Ciencias Biomédicas, Universidad Nacional Autónoma de México (UNAM) and received fellowship 463924 from CONACYT.

\section{Author Contributions}

Tatiana Fiordelisio was responsible for the conception and design of the general line of the work, while Edgar Jiménez-Díaz and Diana Del-Rio contributed to the literature search and significant knowledge input. All authors participated in the drafting of the manuscript, critical revision of the intellectual content, and final approval of the version to be published.

\section{References}

1 Biedl A. Innere sekretion. Arch Inter Med. 1911;VII(3):438-40.

2 Fink G. 60 year of neuroendocrinology: memoir - Harris' neuroendocrine revolution: of portal vessels and self-priming. J Endocrinol. 2015 Aug;226(2):T13-24.

3 Ramón y Cajal S. Histologie du système nerveux de l'homme \& des vertébrés. Paris: Maloine; 1909.

4 Dawson AB. Differential staining of the anterior pituitary gland of the cat. Stain Technology. 1939;14(4):133-8.

5 Terai T, Nagano T. Small-molecule fluorophores and fluorescent probes for bioimaging. Pflugers Arch. 2013 Mar;465(3):347-59.
6 Lichtman JW, Conchello JA. Fluorescence microscopy. Nat Methods. 2005 Dec;2(12): 910-9.

7 Chalfie M. GFP: lighting up life (nobel lecture). Angew Chem Int Ed Engl. 2009;48(31): 5603-11.

8 Craggs TD. Green fluorescent protein: structure, folding and chromophore maturation. Chem Soc Rev. 2009 Oct;38(10):2865-75.

9 Shimomura O. Discovery of green fluorescent protein (GFP) (nobel lecture). Angew Chem Int Ed Engl. 2009;48(31):5590-602.

10 Zheng Q, Lavis LD. Development of photostable fluorophores for molecular imaging. Curr Opin Chem Biol. 2017 Aug;39:32-8.
11 Chalfie M, Tu Y, Euskirchen G, Ward WW, Prasher DC. Green fluorescent protein as a marker for gene expression. Science. $1994 \mathrm{Feb}$ 11;263(5148):802-5.

12 Shaner NC, Patterson GH, Davidson MW. Advances in fluorescent protein technology. J Cell Sci. 2007;120:4247-60.

13 Specht EA, Braselmann E, Palmer AE. A critical and comparative review of fluorescent tools for live-cell imaging. Annu Rev Physiol. 2017 Feb 10;79:93-117.

14 Kubitscheck U, Tschödrich-Rotter M, Wedekind P, Peters R. Two-photon scanning microphotolysis for three-dimensional data storage and biological transport measurements. J Microsc. 1996 Jun;182(Pt 3):225-33. 
15 Renz M. Fluorescence microscopy: a historical and technical perspective. Cytometry A. 2013;83:767-79.

16 Peters R, Peters J, Tews KH, Bähr W. A microfluorimetric study of translational diffusion in erythrocyte membranes. Biochim Biophys Acta. 1974 Nov 15;367(3):282-94.

17 Jacobson K, Derzko Z, Wu ES, Hou Y, Poste G. Measurement of the lateral mobility of cell surface components in single, living cells by fluorescence recovery after photobleaching. J Supramol Struct. 1976;5(4):565(417)76(428).

18 Selvin PR. Fluorescence resonance energy transfer. Methods Enzymol.1995;246:300-34.

19 Berney C, Danuser G. FRET or no FRET: a quantitative comparison. Biophys J. 2003 Jun; 84(6):3992-4010.

20 Mattheyses AL, Simon SM, Rappoport JZ. Imaging with total internal reflection fluorescence microscopy for the cell biologist. J Cell Sci. 2010 Nov 1;123(Pt 21):3621-8.

21 Dannies PS. Protein hormone storage in secretory granules: mechanisms for concentration and sorting. Endocr Rev. 1999 Feb;20(1): 3-21.

22 Toomre D, Keller P, White J, Olivo JC, Simons K. Dual-color visualization of transGolgi network to plasma membrane traffic along microtubules in living cells. J Cell Sci. 1999 Jan 1;112(Pt 1):21-33.

23 Wang L, Frei MS, Salim A, Johnsson K. Smallmolecule fluorescent probes for live-cell super-resolution microscopy. J Am Chem Soc. 2019 Feb 20;141(7):2770-81.

24 Schermelleh L, Ferrand A, Huser T, Eggeling C, Sauer M, Biehlmaier O, et al. Super-resolution microscopy demystified. Nat Cell Biol. 2019 Jan;21(1):72-84.

25 Sigal YM, Zhou R, Zhuang X. Visualizing and discovering cellular structures with superresolution microscopy. Science. 2018 Aug 31; 361(6405):880-7.

26 Sahl SJ, Hell SW, Jakobs S. Fluorescence nanoscopy in cell biology. Nat Rev Mol Cell Biol. 2017 Nov;18(11):685-701.

27 Chen B-C, Legant WR, Wang K, Shao L, Milkie DE, Davidson MW, et al. Lattice lightsheet microscopy: imaging molecules to embryos at high spatiotemporal resolution. Science. 2014 Oct 24;346(6208): 1257998.

28 Freundlich MM. Origin of the electron microscope. Science. 1963;142(3589):185-8.

29 Koster AJ, Klumperman J. Electron microscopy in cell biology: integrating structure and function. Nat Rev Mol Cell Biol. 2003 Sep: SS6-10.

30 de Jonge N, Ross FM. Electron microscopy of specimens in liquid. Nat Nanotechnol. 2011 Oct 23;6(11):695-704.

31 Gray AB. Analysis of diameters of human pituitary hormone secretory granules. Acta Endocrinol. 1977 Jun;85(2):249-55.

32 Peddie CJ, Collinson LM. Exploring the third dimension: volume electron microscopy comes of age. Micron. 2014 Jun;61:9-19.

33 Kizilyaprak C, Daraspe J, Humbel BM. Fo- cused ion beam scanning electron microscopy in biology. J Microsc. 2014 Jun;254(3): 109-14.

34 Cajal SRY., RamónCajal yS. Histologie du système nerveux de l'homme \& des vertébrés. 1909.

35 Popa G. A portal circulation from the pituitary to the hypothalamic region. J Anat. 1930 Oct;65(Pt 1):88-91.

36 Guillemin R, Burgus R. The hormones of the hypothalamus. Sci Am. 1972;227(5):24-33.

37 Page RB, Bergland RM. The neurohypophyseal capillary bed. I. Anatomy and arterial supply. Am J Anat. 1977 Mar;148(3):345-57.

38 Gutnick A, Blechman J, Kaslin J, Herwig L, Belting H-G, Affolter M, et al. The hypothalamic neuropeptide oxytocin is required for formation of the neurovascular interface of the pituitary. Dev Cell. 2011 Oct 18;21(4): 642-54.

39 Chen Q, Leshkowitz D, Blechman J, Levkowitz G. Single-cell molecular and cellular architecture of the mouse neurohypophysis. eNeuro. 2020 Jan 17;7(1).

40 Anbalagan S, Gordon L, Blechman J, Matsuoka RL, Rajamannar P, Wircer E, et al. Pituicyte cues regulate the development of permeable neuro-vascular interfaces. Dev Cell. 2018 Dec 17;47(6):711-26.

41 Guillemin R. The adenohypophysis and its hypothalamic control. Annu Rev Physiol. 1967;29:313-48.

42 Monroe BG, Paull WK. Ultrastructural changes in the hypothalamus during development and hypothalamic activity: the median eminence. Prog Brain Res. 1974;41:185-208.

43 Miyata S. Advances in understanding of structural reorganization in the hypothalamic neurosecretory system. Front Endocrinol. 2017 Oct 17;8:275.

44 Duquenne M, Folgueira C, Bourouh C, Millet M, Silva A, Clasadonte J, et al. Leptin brain entry via a tanycytic LepR-EGFR shuttle controls lipid metabolism and pancreas function. Nat Metab. 2021 Aug;3(8):1071-90.

45 Lhomme T, Clasadonte J, Imbernon M, Fernandois D, Sauve F, Caron E, et al. Tanycytic networks mediate energy balance by feeding lactate to glucose-insensitive POMC neurons. J Clin Invest. 2021 Sep 15;131(18):e140521.

46 Schaeffer M, Langlet F, Lafont C, Molino F, Hodson DJ, Roux T, et al. Rapid sensing of circulating ghrelin by hypothalamic appetitemodifying neurons. Proc Natl Acad Sci U S A. 2013 Jan 22;110(4):1512-7.

47 Clarke IJ. Hypothalamus as an endocrine organ. Compr Physiol. 2015 Jan;5(1):217-53.

48 Jiang H, Gallet S, Klemm P, Scholl P, FolzDonahue K, Altmüller J, et al. MCH neurons regulate permeability of the median eminence barrier. Neuron. 2020 Jul 22;107(2):306-19.

49 Rummelt V, Gardner LM, Folberg R, Beck S, Knosp B, Moninger TO, et al. Three-dimensional relationships between tumor cells and microcirculation with double cyanine immunolabeling, laser scanning confocal microscopy, and computer-assisted reconstruction: an alternative to cast corrosion preparations. J Histochem Cytochem. 1994;42:681-6.

50 Itoh J, Kawai K, Serizawa A, Yasumura K, Ogawa K, Osamura RY. A new approach to three-dimensional reconstructed imaging of hormone-secreting cells and their microvessel environments in rat pituitary glands by confocal laser scanning microscopy. J Histochem Cytochem. 2000 Apr;48(4):569-78.

51 Itoh J, Serizawa A, Kawai K, Ishii Y, Teramoto A, Osamura RY. Vascular networks and endothelial cells in the rat experimental pituitary glands and in the human pituitary adenomas. Microsc Res Tech. 2003 Feb 1;60(2):231-5.

52 Satoh H, Inokuchi T, Shimizu M, Obayashi H, Nakashima Y. Ultrastructure of the hypophyseal portal vessel in mature rats. SEM and TEM observations. Kurume Med J. 1989;36: 91-4.

53 Fujiwara K, Jindatip D, Kikuchi M, Yashiro T. In situ hybridization reveals that type I and III collagens are produced by pericytes in the anterior pituitary gland of rats. Cell Tissue Res. 2010 Dec;342(3):491-5.

54 Jindatip D, Fujiwara K, Kouki T, Yashiro T. Transmission and Scanning Electron Microscopy Study of the characteristics and morphology of pericytes and novel desmin-immunopositive perivascular cells before and after castration in rat anterior pituitary gland. Anat Sci Int. 2012 Sep;87(3):165-73.

55 Tissier PL, Le Tissier P, Campos P, Lafont C, Romanò N, Hodson DJ, et al. An updated view of hypothalamic-vascular-pituitary unit function and plasticity. Nat Rev Endocrinol. 2017;13:257-67.

56 Lafont C, Desarmenien MG, Cassou M, Molino F, Lecoq J, Hodson D, et al. Cellular in vivo imaging reveals coordinated regulation of pituitary microcirculation and GH cell network function. Proc Natl Acad Sci U S A. 2010;107:4465-70.

57 Hodson DJ, Schaeffer M, Romanò N, Fontanaud P, Lafont C, Birkenstock J, et al. Existence of long-lasting experience-dependent plasticity in endocrine cell networks. Nat Commun. 2012 Jan 3;3:605.

58 Schaeffer M, Hodson DJ, Lafont C, Mollard P Functional importance of blood flow dynamics and partial oxygen pressure in the anterior pituitary. Eur J Neurosci. 2010;32:2087-95.

59 Ward RD, Stone BM, Raetzman LT, Camper SA. Cell proliferation and vascularization in mouse models of pituitary hormone deficiency. Mol Endocrinol. 2006 Jun;20(6):1378-90.

60 Korsisaari N, Ross J, Wu X, Kowanetz M, Pal $\mathrm{N}$, Hall L, et al. Blocking vascular endothelial growth factor-A inhibits the growth of pituitary adenomas and lowers serum prolactin level in a mouse model of multiple endocrine neoplasia type 1. Clin Cancer Res. 2008 Jan 1; 14(1):249-58.

61 Hunter RL. 20th annual meeting of the histochemical society, Atlantic City, April 12-13, 1969. Symposium on hormone localization in cells and tissues. J Histochem Cytochem. 1970 Jan;18(1):1-8. 
62 Nakane PK. Classifications of anterior pituitary cell types with immunoenzyme histochemistry. J Histochem Cytochem. 1970 Jan; 18(1):9-20.

63 Attia MA. A modified tetrachrome staining technique for the adenohypophysis of dogs, rats and rabbits. Arch Toxicol. 1978 Aug 9; 40(4):295-301.

64 Villarreal ML, Lee P, Garnica A, González H, Larraza O, Valverde C. Polichromic staining of five distinct cellular types in human and rat pituitaries. Bol Estud Med Biol. 1987 Jul; 35(3-4):231-8.

65 Wen S, Schwarz JR, Niculescu D, Dinu C, Bauer CK, Hirdes W, et al. Functional characterization of genetically labeled gonadotropes. Endocrinology. 2008 Jun; 149(6): 2701-11.

66 Pérez-Millán MI, Zeidler MG, Saunders TL, Camper SA, Davis SW. Efficient, specific, developmentally appropriate cre-mediated recombination in anterior pituitary gonadotropes and thyrotropes. Genesis. 2013 Nov; 51(11):785-92.

67 Castinetti F, Brinkmeier ML, Gordon DF, Vella KR, Kerr JM, Mortensen AH, et al. PITX2 AND PITX1 regulate thyrotroph function and response to hypothyroidism. Mol Endocrinol. 2011 Nov;25(11):1950-60.

68 Magoulas C, McGuinness L, Balthasar N, Carmignac DF, Sesay AK, Mathers KE, et al. A secreted fluorescent reporter targeted to pituitary growth hormone cells in transgenic mice. Endocrinology. 2000 Dec; 141(12): 4681-9.

69 He Z, Fernandez-Fuente M, Strom M, Cheung L, Robinson IC, Le Tissier P. Continuous online monitoring of secretion from rodent pituitary endocrine cells using fluorescent protein surrogate markers. J Neuroendocrinol. 2011 Mar;23(3):197-207.

70 Budry L, Lafont C, El Yandouzi T, Chauvet N, Conéjero G, Drouin J, et al. Related pituitary cell lineages develop into interdigitated 3D cell networks. Proc Natl Acad Sci U S A. 2011 Jul 26;108(30):12515-20.

71 Lavoie PL, Budry L, Balsalobre A, Drouin J. Developmental dependence on NurRE and EboxNeuro for expression of pituitary proopiomelanocortin. Mol Endocrinol. 2008 Jul; 22(7):1647-57.

72 Santiago-Andres Y, Golan M, Fiordelisio T. Functional pituitary networks in vertebrates. Front Endocrinol. 2020;11:619352.

73 Panchuk-Voloshina N, Haugland RP, Bishop-Stewart J, Bhalgat MK, Millard PJ, Mao F, et al. Alexa dyes, a series of new fluorescent dyes that yield exceptionally bright, photostable conjugates. J Histochem Cytochem. 1999 Sep;47(9):1179-88.

74 Noda T, Kaidzu S, Kikuchi M, Yashiro T. Topographic affinities of hormone-producing cells in the rat anterior pituitary gland. Acta Histochem Cytochem. 2001;34(5):313-
75 Hodson DJ, Mollard P. Navigating pituitary structure and function: defining a roadmap for hormone secretion. J Neuroendocrinol. 2013 Jul;25(7):674-5.

76 Seuntjens E, Vankelecom H, Quaegebeur A, Vande Vijver V, Denef C. Targeted ablation of gonadotrophs in transgenic mice affects embryonic development of lactotrophs. $\mathrm{Mol}$ Cell Endocrinol. 1999 Apr 25;150(1-2):12939.

77 Waite E, Lafont C, Carmignac D, Chauvet N, Coutry N, Christian H, et al. Different degrees of somatotroph ablation compromise pituitary growth hormone cell network structure and other pituitary endocrine cell types. Endocrinology. 2010 Jan;151(1):234-43.

78 Mollard P, Hodson DJ, Lafont C, Rizzoti K, Drouin J. A tridimensional view of pituitary development and function. Trends Endocrinol Metab. 2012 Jun;23(6):261-9.

79 Le Tissier PR, Hodson DJ, Lafont C, Fontanaud P, Schaeffer M, Mollard P. Anterior pituitary cell networks. Front Neuroendocrinol. 2012 Aug;33(3):252-66.

80 Bonnefont X, Lacampagne A, Sanchez-Hormigo A, Fino E, Creff A, Mathieu MN, et al. Revealing the large-scale network organization of growth hormone-secreting cells. Proc Natl Acad Sci U S A. 2005 Nov 15;102(46): 16880-5.

81 Sanchez-Cardenas C, Fontanaud P, He Z, Lafont C, Meunier AC, Schaeffer M, et al. Pituitary growth hormone network responses are sexually dimorphic and regulated by gonadal steroids in adulthood. Proc Natl Acad Sci U S A. 2010 Dec 14;107(50):21878-83.

82 Schaeffer M, Hodson DJ, Meunier A-C, Lafont C, Birkenstock J, Carmignac D, et al. Influence of estrogens on GH-cell network dynamics in females: a live in situ imaging approach. Endocrinology. 2011 Dec;152(12): 4789-99.

83 Navratil AM, Knoll JG, Whitesell JD, Tobet SA, Clay CM. Neuroendocrine plasticity in the anterior pituitary: gonadotropin-releasing hormone-mediated movement in vitro and in vivo. Endocrinology. 2007 Apr;148(4): 1736-44.

84 Fontaine R, Ager-Wick E, Hodne K, Weltzien FA. Plasticity in medaka gonadotropes via cell proliferation and phenotypic conversion. J Endocrinol. 2020 Apr;245(1):21-37.

85 Grønlien HK, Fontaine R, Hodne K, Tysseng I, Ager-Wick E, Weltzien F-A, et al. Long extensions with varicosity-like structures in gonadotrope Lh cells facilitate clustering in medaka pituitary culture. PLoS One. 2021 Jan 28; 16(1):e0245462.

86 Ravi M, Paramesh V, Kaviya SR, Anuradha E, Solomon FD. 3D cell culture systems: advantages and applications. J Cell Physiol. 2015 Jan;230(1):16-26.

87 Wu Q, Liu J, Wang X, Feng L, Wu J, Zhu X, et al. Organ-on-a-chip: recent breakthroughs and future prospects. BioMed Eng Online. 2020;19(1):9.
88 Denef C, Maertens P, Allaerts W, Mignon A, Robberecht W, Swennen L, et al. Cell-to-cell communication in peptide target cells of anterior pituitary. Methods Enzymol. 1989;168: 47-71.

89 Denef C, Andries M. Evidence for paracrine interaction between gonadotrophs and lactotrophs in pituitary cell aggregates. Endocrinology. 1983 Mar;112(3):813-22.

90 Pals K, Vankelecom H, Denef C. Triiodothyronine expands the lactotroph and maintains the lactosomatotroph population, whereas thyrotrophin-releasing hormone augments thyrotroph abundance in aggregate cell cultures of postnatal rat pituitary gland. J Neuroendocrinol. 2006 Mar;18(3):203-16.

91 Pals K, Roudbaraki M, Denef C. Growth hormone-releasing hormone and glucocorticoids determine the balance between luteinising hormone (LH) beta- and LH beta/folliclestimulating hormone beta-positive gonadotrophs and somatotrophs in the 14-day-old rat pituitary tissue in aggregate cell culture. J Neuroendocrinol. 2008 May; 20(5):535-48.

92 Hauspie A, Seuntjens E, Vankelecom H, Denef C. Stimulation of combinatorial expression of prolactin and glycoprotein hormone alpha-subunit genes by gonadotropin-releasing hormone and estradiol-17beta in single rat pituitary cells during aggregate cell culture. Endocrinology. 2003 Jan;144(1):388-99.

93 Denef C. Paracrinicity: the story of 30 years of cellular pituitary crosstalk. J Neuroendocrinol. 2008 Jan;20(1):1-70.

94 Tsukada T, Kouki T, Fujiwara K, Ramadhani D, Horiguchi K, Kikuchi M, et al. Reassembly of anterior pituitary organization by hanging drop three-dimensional cell culture. Acta Histochem Cytochem. 2013 Aug 29;46(4): 121-7.

95 Michon L, Nlend Nlend R, Bavamian S, Bischoff L, Boucard N, Caille D, et al. Involvement of gap junctional communication in secretion. Biochim Biophys Acta. 2005 Dec 20; 1719(1-2):82-101.

96 Vitale ML, Pelletier RM. The anterior pituitary gap junctions: potential targets for toxicants. Reprod Toxicol. 2018 Aug;79:72-8.

97 Morand I, Fonlupt P, Guerrier A, Trouillas J, Calle A, Remy C, et al. Cell-to-cell communication in the anterior pituitary: evidence for gap junction-mediated exchanges between endocrine cells and folliculostellate cells. Endocrinology. 1996 Aug;137(8):3356-67.

98 Meda P, Pepper MS, Traub O, Willecke K, Gros D, Beyer E, et al. Differential expression of gap junction connexins in endocrine and exocrine glands. Endocrinology. $1993 \mathrm{Nov}$ 133(5):2371-8.

99 Hunter J. Observations on certain parts of the animal oeconomy: by John Hunter. 2nd ed. 1792. p. 284. 
100 Wilson JD. Charles-Edouard brown-sequard and the centennial of endocrinology. The J Clin Endocrinol Metab. 1990;71(6): 1403-9.

101 Montón H, Nogués C, Rossinyol E, Castell O, Roldán M. QDs versus Alexa: reality of promising tools for immunocytochemistry. J Nanobiotechnology. 2009 May 27;7:4.

102 Matsuno A, Mizutani A, Okinaga H, Takano K, Yamada S, Yamada SM, et al. Functional molecular morphology of anterior pituitary cells, from hormone production to intracellular transport and secretion. Med Mol Morphol. 2011 Jun;44(2):63-70.

103 Matsuno A, Itoh J, Takekoshi S, Nagashima T, Osamura RY. Three-dimensional imaging of the intracellular localization of growth hormone and prolactin and their mRNA using nanocrystal (Quantum dot) and confocal laser scanning microscopy techniques. J Histochem Cytochem. 2005 Jul;53(7):8338.

104 Harper CV, Featherstone K, Semprini S, Friedrichsen S, McNeilly J, Paszek P, et al. Dynamic organisation of prolactin gene expression in living pituitary tissue. J Cell Sci. 2010 Feb 1;123(Pt 3):424-30.

105 Featherstone K, White MR, Davis JR. The prolactin gene: a paradigm of tissue-specific gene regulation with complex temporal transcription dynamics. J Neuroendocrinol. 2012 Jul;24(7):977-90.

106 Featherstone K, Hey K, Momiji H, McNamara AV, Patist AL, Woodburn J, et al. Spatially coordinated dynamic gene transcription in living pituitary tissue. Elife. $2016 \mathrm{Feb}$ 1;5:e08494.

107 Lamberts SW, Macleod RM. Regulation of prolactin secretion at the level of the lactotroph. Physiol Rev. 1990;70:279-318.

108 Cochilla AJ, Angleson JK, Betz WJ. Differential regulation of granule-to-granule and granule-to-plasma membrane fusion during secretion from rat pituitary lactotrophs. J Cell Biol. 2000 Aug 21;150(4):839-48.

109 Vardjan N, Jorgacevski J, Stenovec M, Kreft M, Zorec R. Compound exocytosis in pituitary cells. Ann N Y Acad Sci. 2009 Jan;1152: 63-75.

110 Orci L, Malaisse W. Hypothesis: single and chain release of insulin secretory granules is related to anionic transport at exocytotic sites. Diabetes. 1980;29(11):943-4.

111 Hoppa MB, Jones E, Karanauskaite J, Ramracheya R, Braun M, Collins SC, et al. Multivesicular exocytosis in rat pancreatic beta cells. Diabetologia. 2012 Apr;55(4):1001-12.

112 Schmoranzer J, Goulian M, Axelrod D, Simon SM. Imaging constitutive exocytosis with total internal reflection fluorescence microscopy. J Cell Biol. 2000;149:23-32.

113 Lang T, Wacker I, Steyer J, Kaether C, Wunderlich I, Soldati T, et al. Ca2+-triggered peptide secretion in single cells imaged with green fluorescent protein and evanescentwave microscopy. Neuron. 1997 Jun;18(6): 857-63.
114 Taraska JW, Perrais D, Ohara-Imaizumi M, Nagamatsu S, Almers W. Secretory granules are recaptured largely intact after stimulated exocytosis in cultured endocrine cells. Proc Natl Acad Sci U S A. 2003 Feb 18;100(4): 2070-5.

115 Ohara-Imaizumi M, Nishiwaki C, Kikuta T, Nagai S, Nakamichi Y, Nagamatsu S. TIRF imaging of docking and fusion of single insulin granule motion in primary rat pancreatic beta-cells: different behaviour of granule motion between normal and Goto-Kakizaki diabetic rat beta-cells. Biochem J. 2004 Jul 1; 381(Pt 1):13-8.

116 Ma L, Bindokas VP, Kuznetsov A, Rhodes C, Hays L, Edwardson JM, et al. Direct imaging shows that insulin granule exocytosis occurs by complete vesicle fusion. Proc Natl Acad Sci U S A. 2004 Jun 22;101(25):9266-71.

117 Dang AK, Chaplin NL, Murtazina DA, Boehm U, Clay CM, Amberg GC. Subplasmalemmal hydrogen peroxide triggers calcium influx in gonadotropes. J Biol Chem. 2018 Oct 12;293(41):16028-42.

118 McGuinness L, Magoulas C, Sesay AK, Mathers K, Carmignac D, Manneville JB, et al. Autosomal dominant growth hormone deficiency disrupts secretory vesicles in vitro and in vivo in transgenic mice. Endocrinology. 2003 Feb;144(2):720-31.

119 Yoshitomi M, Ohta K, Kanazawa T, Togo A, Hirashima S, Uemura K-I, et al. Three-dimensional ultrastructural analyses of anterior pituitary gland expose spatial relationships between endocrine cell secretory granule localization and capillary distribution. Sci Rep. 2016 Oct 31;6:36019.

120 Sower SA. Breaking Dogma on the Hypothalamic-Pituitary Anatomical Relations in Vertebrates. Endocrinology. 2015 Nov; 156(11):3882-4.

121 Golan M, Zelinger E, Zohar Y, Levavi-Sivan B. Architecture of GnRH-gonadotrope-vasculature reveals a dual mode of gonadotropin regulation in fish. Endocrinology. 2015 Nov;156(11):4163-73.

122 Berridge MJ, Bootman MD, Roderick HL Calcium signalling: dynamics, homeostasis and remodelling. Nat Rev Mol Cell Biol. 2003 Jul;4(7):517-29.

123 Berridge MJ, Lipp P, Bootman MD. The versatility and universality of calcium signalling. Nat Rev Mol Cell Biol. 2000 Oct;1(1): 11-21.

124 Stojilkovic SS, Tabak J, Bertram R. Ion channels and signaling in the pituitary gland. Endocr Rev. 2010;31:845-915.

125 Zemková H, Stojilkovic SS. Neurotransmitter receptors as signaling platforms in anterior pituitary cells. Mol Cell Endocrinol. 2018 Mar 5;463:49-64.

126 Zivadinovic D, Tomić M, Yuan D, Stojilkovic SS. Cell-type specific messenger functions of extracellular calcium in the anterior pituitary. Endocrinology. 2002 Feb;143(2):44555.
127 Kwiecien R, Hammond C. Differential management of $\mathrm{Ca} 2+$ oscillations by anterior pituitary cells: a comparative overview. Neuroendocrinology. 1998 Sep;68(3):135-51.

128 Sato M, Ozawa T, Inukai K, Asano T, Umezawa Y. Fluorescent indicators for imaging protein phosphorylation in single living cells. Nat Biotechnol. 2002 Mar;20(3): 287-94.

129 Ohta Y, Furuta T, Nagai T, Horikawa K. Red fluorescent cAMP indicator with increased affinity and expanded dynamic range. Sci Rep. 2018 Jan 30;8(1):1866.

130 Odaka H, Arai S, Inoue T, Kitaguchi T. Genetically-encoded yellow fluorescent cAMP indicator with an expanded dynamic range for dual-color imaging. PLoS One. 2014 Jun 24;9(6):e100252.

131 Duncan PJ, Sengül S, Tabak J, Ruth P, Bertram R, Shipston MJ. Large conductance $\mathrm{Ca} 2+$-activated $\mathrm{K}+(\mathrm{BK})$ channels promote secretagogue-induced transition from spiking to bursting in murine anterior pituitary corticotrophs. J Physiol. 2015 Mar 1;593(5): 1197-211.

132 Tse A, Tse FW, Almers W, Hille B. Rhythmic exocytosis stimulated by GnRH-induced calcium oscillations in rat gonadotropes. Science. 1993 Apr 2;260(5104):82-4.

133 Ritchie AK. Thyrotropin-releasing hormone stimulates a calcium-activated potassium current in a rat anterior pituitary cell line. J Physiol. 1987 Apr;385:611-25.

134 Storace D, Rad MS, Han Z, Jin L, Cohen LB, Hughes T, et al. Genetically Encoded Protein Sensors of Membrane Potential. Adv Exp Med Biol. 2015;859:493-509.

135 Beck A, Götz V, Qiao S, Weissgerber P, Flockerzi V, Freichel M, et al. Functional Characterization of Transient Receptor Potential (TRP) Channel C5 in Female Murine Gonadotropes. Endocrinology. 2017 Apr 1; 158(4):887-902.

$136 \mathrm{Li} \mathrm{WH}$. Probes for monitoring regulated exocytosis. Cell Calcium. 2017 Jun;64:65-71.

137 Zhang L, Liang B, Barbera G, Hawes S, Zhang Y, Stump K, et al. Miniscope GRIN lens system for calcium imaging of neuronal activity from deep brain structures in behaving animals. Curr Protoc Neurosci. 2019 Jan; 86(1):e56.

138 Takahashi A, Camacho P, Lechleiter JD, Herman B. Measurement of intracellular calcium. Physiol Rev. 1999 Oct;79(4):1089125.

139 Chen T-W, Wardill TJ, Sun Y, Pulver SR, Renninger SL, Baohan A, et al. Ultrasensitive fluorescent proteins for imaging neuronal activity. Nature. 2013 Jul 18;499(7458):295300.

140 Whitaker M. Genetically encoded probes for measurement of intracellular calcium. Methods Cell Biol. 2010;99:153-82.

141 Kotlikoff MI. Genetically encoded Ca2+ indicators: using genetics and molecular design to understand complex physiology. J Physiol. 2007 Jan 1;578(Pt 1):55-67. 
142 Li ES, Saha MS. Optimizing calcium detection methods in animal systems: a sandbox for synthetic biology. Biomolecules. 2021 Feb 24;11(3):343.

143 Kim H, Kim M, Im SK, Fang S. Mouse CreLoxP system: general principles to determine tissue-specific roles of target genes. Lab Anim Res. 2018 Dec;34(4):147-59.

144 Iida T, Stojilković SS, Izumi S, Catt KJ. Spontaneous and agonist-induced calcium oscillations in pituitary gonadotrophs. Mol Endocrinol. $1991 \mathrm{Jul} ; 5(7): 949-58$.

145 Tomić M, Cesnajaj M, Catt KJ, Stojilkovic SS. Developmental and physiological aspects of $\mathrm{Ca} 2+$ signaling in agonist-stimulated pituitary gonadotrophs. Endocrinology. 1994 Nov;135(5):1762-71.

146 Durán-Pastén ML, Fiordelisio T. GnRH-induced $\mathrm{Ca}(2+)$ signaling patterns and gonadotropin secretion in pituitary gonadotrophs. Functional adaptations to both ordinary and extraordinary physiological demands. Front Endocrinol. 2013 Sep 30;4:127.

147 Durán-Pastén ML, Fiordelisio-Coll T, Hernández-Cruz A. Castration-induced modifications of GnRH-elicited (Ca2+) (i) signaling patterns in male mouse pituitary gonadotrophs in situ: Studies in the Acute Pituitary Slice Preparation. Biol Reprod. 2013 Feb;88(2):38.

148 Holl RW, Thorner MO, Mandell GL, Sullivan JA, Sinha YN, Leong DA. Spontaneous oscillations of intracellular calcium and growth hormone secretion. J Biol Chem. 1988 Jul 15;263(20):9682-5.

149 Johnson JD, Klausen C, Habibi HR, Chang JP. Function-specific calcium stores selectively regulate growth hormone secretion, storage, and mRNA level. Am J Physiol Endocrinol Metab. 2002;282:E810.

150 Ghosh KK, Burns LD, Cocker ED, Nimmerjahn A, Ziv Y, Gamal AE, et al. Miniaturized integration of a fluorescence microscope. Nat Methods. 2011 Sep 11;8(10):871-8.

151 Bigas M, Cabruja E, Forest J, Salvi J. Review of CMOS image sensors. Microelectronics J. 2006;37(5):433-51.

152 Cho J, Park JH, Kim JK, Fred Schubert E. White light-emitting diodes: History, progress, and future. Laser Photonics Rev. 2017; 11:1600147.

153 Kemkem Y, Guillou A, Lafont C, Fontanaud P, El Cheikh L, Camper S, et al. SAT-547 pituitary thyrotrophs: a generator of repetitive calcium waves in freely-moving animal models. J Endocr Soc. 2019 Apr 30.

154 Hoa O, Lafont C, Fontanaud P, Guillou A, Kemkem Y, Kineman RD, et al. Imaging and manipulating pituitary function in the awake mouse. Endocrinology. 2019 Oct 1; 160(10):2271-81.

155 Bargmann W. Neurosecretion. Int Rev Cytol. 1966;19:183-201.

156 Schwerdtfeger LA, Tobet SA. From organotypic culture to body-on-a-chip: a neuroendocrine perspective. J Neuroendocrinol. 2019 Mar;31(3):e12650.

157 Campos P, Walker JJ, Mollard P. Diving into the brain: deep-brain imaging techniques in conscious animals. J Endocrinol. 2020 Aug; 246(2):R33-50.

158 Ballato J, Dragic P. Glass: the carrier of light - a brief history of optical fiber. Int J Appl Glass Sci. 2016;7(4):413-22.

159 Steiner R. New laser technology and future applications. Med Laser Appl. 2006;21(2): 131-40.

160 Fenno L, Yizhar O, Deisseroth K. The development and application of optogenetics. Annu Rev Neurosci. 2011;34:389-412.

161 Wang Y, DeMarco EM, Witzel LS, Keighron JD. A selected review of recent advances in the study of neuronal circuits using fiber photometry. Pharmacol Biochem Behav. 2021 Feb;201:173113.

162 Han SY, Kane G, Cheong I, Herbison AE. Characterization of GnRH pulse generator activity in male mice using GCaMP fiber photometry. Endocrinology. 2019 Mar 1; 160(3):557-67.

163 Clarkson J, Han SY, Piet R, McLennan T, Kane GM, Ng J, et al. Definition of the hypothalamic GnRH pulse generator in mice. Proc Natl Acad Sci U S A. 2017 Nov 21; 114(47):E10216-23.

164 Vanacker C, Anthony Defazio R, Sykes CM, Moenter SM. A role for glial fibrillary acidic protein (GFAP)-expressing cells in the regulation of gonadotropin-releasing hormone (GnRH) but not arcuate kisspeptin neuron output in male mice. ELife. 2021;10:e68205:

165 Mahmoudi P, Veladi H, Pakdel FG. Optogenetics, tools and applications in neurobiology. J Med Signals Sens. 2017 Apr;7(2):71-9.

166 Mattis J, Tye KM, Ferenczi EA, Ramakrishnan C, O'Shea DJ, Prakash R, et al. Principles for applying optogenetic tools derived from direct comparative analysis of microbial op- sins. Nat Methods. 2011 Dec 18;9(2):15972.

167 Schneider F, Grimm C, Hegemann P. Biophysics of channelrhodopsin. Annu Rey Biophys. 2015;44:167-86.

168 Huh D, Hamilton GA, Ingber DE. From 3D cell culture to organs-on-chips. Trends Cell Biol. 2011 Dec;21(12):745-54.

169 Corrò C, Novellasdemunt L, Li VSW. A brief history of organoids. Am J Physiol Cell Physiol. 2020 Jul 1;319(1):C151-65.

170 Krokker L, Szabó B, Németh K, Tóháti R, Sarkadi B, Mészáros K, et al. Three dimensional cell culturing for modeling adrenal and pituitary tumors. Pathol Oncol Res. 2021;27.

171 Carvalho V, Gonçalves I, Lage T, Rodrigues RO, Minas G, Teixeira SFCF, et al. 3D printing techniques and their applications to organ-on-a-chip platforms: a systematic review. Sensors. 2021 May 10;21(9):3304.

172 Legant WR, Shao L, Grimm JB, Brown TA, Milkie DE, Avants BB, et al. High-density three-dimensional localization microscopy across large volumes. Nat Methods. 2016 Apr;13(4):359-65.

173 Susaki EA, Shimizu C, Kuno A, Tainaka K, Li X, Nishi K, et al. Versatile whole-organ/ body staining and imaging based on electrolyte-gel properties of biological tissues. Nat Commun. 2020 Apr 27;11(1):1982.

174 Zong W, Wu R, Li M, Hu Y, Li Y, Li J, et al. Fast high-resolution miniature two-photon microscopy for brain imaging in freely behaving mice. Nat Methods. 2017 Jul;14(7): 713-9.

175 Srinivasan S, Hosokawa T, Vergara P, Chérasse Y, Naoi T, Sakurai T, et al. Miniaturized microscope with flexible light source input for neuronal imaging and manipulation in freely behaving animals. Biochem Biophys Res Commun. 2019 Sep 24;517(3):520-4.

176 Bindocci E, Savtchouk I, Liaudet N, Becker D, Carriero G, Volterra A. Three-dimensional $\mathrm{Ca} 2+$ imaging advances understanding of astrocyte biology. Science. 2017 May 19;356(6339).

177 Bergland RM, Torack RM. An ultrastructural study of follicular cells in the human anterior pituitary. Am J Pathol. 1969 Nov;57(2): 273-97.

178 Popa Gregor, Fielding Una. The vascular link between the pituitary and the hypothalamus. Lancet. 1930;216(5579):238-240. 